\title{
Eestikeelsed kalanimetused: teaduslikud versus rahvapärased
}

\author{
Mari Kendla
}

Teesid: Artiklis käsitletakse eesti keeles esinevate kalanimede kujunemist, tuuakse esile kaladele nimeandmise põhimõtted nii rahvapärase kui ka teadusliku kategoriseerimise seisukohast ning kõrvutatakse neid printsiipidega, mille järgi on kalanimetusi klassifitseerinud teised rahvad. Praeguseks üldkehtivaid eesti kirjakeelseid kalanimesid hakati moodustama 1920. aastail seoses omakeelse teadusterminoloogia loomisega. Nimede valikul lähtuti sageli teiste keelte, eriti saksakeelse terminoloogia eeskujust. Eestikeelsed rahvalikud (murde) nimetused on saadud lokaalselt ja rahvapäraselt kategoriseerides, põhirõhk on olnud kaladele iseloomulikel tunnustel.

Märksõnad: eesti murded, etnoihtüoloogia, kalanimed, leksikoloogia

\section{Sissejuhatus}

Rahvuskeelsete kalanimetuste puhul saame rääkida kirjakeelsetest ehk teaduslikest nimetustest, mille on liikidele kinnitanud ihtüoloogid, ja rahvapärastest, mille on loonud rahvas, lähtudes oma maailmapildist ja seda väljendavast murdekeelest. Meie maailmapilt pole enam ammu kogemuslik-kaemuslik, vaid teaduslik, mida on kujundanud põhiliselt kooliharidus ja kommunikatsioon. Rahvalikud nimetused põhinevad rahva kogemustel ja elutarkusel.

Kui bioloogias on nime moodustamise aluseks süstemaatika, mis toetub teaduslikule taksonoomiale (perekond > sugukond > selts jne), siis rahvapäraste nimetuste puhul pole nende kindel vastavus teaduslikule taksoninimetusele oluline. See on kõnelejate eneste kogemustest ja loogikast lähtuv süsteem, mida nimetatakse ka rahvataksonoomiaks (Cruse 1986). Et kalapüük on üks ürgsemaid elatusallikaid, on inimestel kujunenud kaladest põhjalikud teadmised. Traditsioonilised kalastusviisid põhinesid arusaamadel liikide harjumuste ja ökoloogia kohta, ka kalanimetuste rahvalik (ja rahvakeelne) süsteem toetub 
nendele teadmistele ehk teisisõnu - nimeandmisel lähtutakse looduslikust reaalsusest.

\section{Teaduslik nimetus ehk termin}

Nagu teaduslik keelekasutus erineb igapäevasest, erineb ka teaduslik terminoloogia rahvapärasest nimesüsteemist. Terminid peavad vastama süstemaatika põhimõtetele. Igale kirjeldatud liigile antakse teaduslik nimetus, mis välistab võimaluse, et ühe ja sama nimega võiks tähistada mitut liiki. Nii saab igal kalaliigil olla ainult üks nimetus, mis on äratuntav ka rahvusvaheliselt, ja selleks on ladinakeelne nimetus. Ladinakeelsetele nimetustele on eri rahvad moodustanud omad rahvuskeelsed vasted. Need vasted on ühtlasi teaduslikud nimetused resp. terminid, kui on fikseeritud nende vastavus ladinakeelsetega, või on rahvapärased, kui seda pole tehtud või pole seda silmas peetudki (Kull \& Koppel 1989: 186).

\section{Rahvapärased nimetused}

Rahvapärased nimetused, nagu öeldud, põhinevad rahva elutarkusel, nimepanemise alused kasvavad välja looduslikust reaalsusest. Nime on andnud inimesed oma elupaiga kaladele kas välimust, eluviisi, püügiaega, -kohta või midagi muud kalale iseloomulikku silmas pidades. Rahvalike nimetuste analüüsimisel võivad aga esile kerkida identifitseerimisprobleemid, millega on oma sõnastiku jaoks materjali kogudes silmitsi seisnud juba F. J. Wiedemann: “...ein Thier, besonders einen Fisch oder Vogel, würde ich, auch wenn es mir vorgewiesen wäre, doch in vielen Fällen nicht im Stande gewesen sein zu bestimmen."

Nimetuste ülekandumine ühelt liigilt teisele toimub teatavate tunnuste ühtivuse korral. Sarnane välimus, käitumine, värvus jne loovad tähendusnihetele soodsa pinnase. Näiteks kalanimetus liivarull liivatrull märgib homonüümina vähemalt viit kalaliiki. Emakala (Zoarces viviparus) kutsutakse saarte ja läänemurdes ka lutsuks. Nimetus hink märgib eesti murretes lutsu, emakala ja vingerjat, aga mitte hinku (Cobitis taenia) ennast. Nimede kattumist kohtab teisteski keeltes. Soome kivikala märgib nii trullingut, võldast, luukaritsat kui ka lepamaimu (eesti kivikala tarvitatakse samuti mitme liigi kohta), läti murretes on emakalal ja lutsul ühiseid nimetusi (nt kuncis). Üldnimetus kala tähistab muu hulgas tähtsamaid püügikalu. Saaremaal ja Hiiumaal on selleks räim (räimes on kala, teistel kaladel on nimed - Jäm), Häädemeestel vimb. Pärnu kalurite ja kalakaupmeeste rääkimisviisi kohaselt aga ei sobinud räime suhtes kasutada nimetust kala, see oli ikka ja alati ainult räim. Soomlased ni- 
metavad kalaks räime ja lõhet, rootslastel märgib aga fisk turska kui ühte nende peamist püügiobjekti. Veel sagedasemad on juhtumid, et kalu on paikkonniti või kihelkonniti nimetatud paljude eri nimetustega. Ogalikul näiteks on üle 80 sünonüümi, mis aga võivad kattuda tema sugukonnakaaslase luukaritsa omadega (vrd ka nt soome piikkikala 'ogalik', 'luukarits'). Niisiis ei ole kalaliigi tuvastamine üksnes rahvapärase nimetuse põhjal kerge.

\section{Etnobioloogia}

Uurimisviisi, mis käsitleb inimese traditsioonilist suhtumist kaladesse ja teadmisi kalade kohta (sh nimetuste analüüsi), kutsutakse etnoihtüoloogiaks. Termini võttis teaduslikus kirjanduses kasutusele ameeriklane Warren T. Morrill 1967. aastal. Etnoihtüoloogia on üks osa humanitaar- ja loodusteaduste piirialal asuvast uurimislõigust, mida nimetatakse etnobioloogiaks. Teadusharuna on etnobioloogia võrdlemisi noor, ent huvi selle ala vastu on rahvusvaheliselt kiiresti kasvanud.

Etnobioloogia uurib loomade ja taimede teadlikku tarvitamist toiduks, raviks ja tooraineks, aga samuti inimese ettekujutusi ning käsitusi loodusest. Esmakordselt kasutati mõistet etnobioloogia 1935. aastal, seejärel selgitas selle olemust täpsemalt Edward F. Castetter artiklis "The Domain of Ethnobiology" (1944). Märksa varem on esinenud termin etnobotaanika, mille lasi 1895. aastal käiku Ameerika Ühendriikide botaanik ja etnoloog John William Harshberger. Siinkohal mainitagu esimest eesti etnobotaanikut Gustav Vilbastet ja tema pärandit suurteose Eesti taimenimetused (1993) näol. Taimenimetuste uurimine on toonud esile nende nimetuste tekkimise eeldused. Kokkuvõtvalt võib öelda, et taimedele anti nimi nende iseloomulike tunnuste või kasutamise alusel. Taimenimed pole juhuslikud, enamikul on mingi kindel mõte, need peegeldavad sagedasti taime omadust, kasutamisviisi, välimust, maitset jne (Vilbaste 1993: 59-60).

Tänu Gustav Vilbaste pärandile ja viljakale elutööle on Eestis sellel alal tehtud veel mitmeid uurimusi - eelkõige eestlaste ravimtaimede tundmise ja nende nimetuste kohta ning on koostatud historistlik eesti rahvameditsiini botaaniline andmebaas HERBA (Kalle \& Sõukand 2011; Sõukand \& Kalle 2008, http://herba.folklore.ee).

Etnobioloogia valdkonna käsitluses tuleb kindlasti mainida ka Mart Mägerit, kelle panust loodussõnavara uurijana ei ole võimalik üle hinnata. Tema tööd (kui välja tuua vaid mõned) annavad ülevaate lindude nimetamise printsiipidest (1961), Eesti linnunimetused (1967) on aga seni ainus kõiki murdeid hõlmav loodussõnavara uurimus, mis oma põhjalikkuses pakub huvi nii lingvistile kui 
ka ornitoloogile. M. Mäger jõudis tegeleda ka kalanimetustega. Tema väljaande Juhend ja nimestik kalanimetuste kogumiseks (1973) eesmärgiks tol hetkel oli ärgitada inimesi kalanimetusi koguma ning nimede kohta kirja panema võimalikult palju ja täpset informatsiooni, ühtlasi andis see ülevaate juba olemasolevast materjalist. Seda väljaannet võib lugeda eesti kalanimetuste uurimise ja nimestiku väljaandmise eeltööks, ent ta on sellisenagi olnud aluseks peaaegu kõikidele hilisematele kala-teemalistele kirjutistele, kus on peetud vajalikuks rahvapäraseid nimetusi esitada. Kogu kalanimetusi puudutava informatsiooni koondas M. Mäger oma kalanimetuste kartoteeki, mis praegu asub Eesti Keele Instituudis. Tema materjalidele toetudes on juba ilmunud ka süsteemseid kalanimetuste uurimusi (Kendla 1997, 1999).

\section{Uurimistemaatika ja materjal}

Käesolev artikkel püüab avardada arusaamu rahvapäraste kalanimetuste nimeandmise põhimõtetest (kõrvutades neid ka teiste maade omadega), mistõttu peatutakse kalanimetuste problemaatikal üldisemalt. Et praegused kirjakeelsed nimetused võivad olla lähtunud rahvakeelest, vaadeldakse eesti kirjakeelsete nimetuste vastavust rahvakeelsetele. Rahvapärastel nimetustel on enamasti oma kindel levikuala ning paljud kirjakeelsed nimetused ei pruugi olla (kõikjal) rahvasuus kuigi tuntud. Sellest lähtuvalt peatutakse küsimusel, kas ja kuivõrd on rahvapärastel kalanimetustel kohta praeguses teaduslikus kalanimede nimestikus.

Artiklis kasutatud murdematerjal pärineb Eesti Keele instituudi murdesõnavara kartoteegist (EKI MK), mille hulka on arvatud ka Mart Mägeri kalanimetuste kartoteek (EKI MKK). See kajastab laias laastus aastate 1840-1940 keelekasutust. Eesti murretest on registreeritud umbes 1500 rahvapärast kalanimetust, mis on antud 73 kalaliigi kohta ${ }^{1}$. See materjal annab võimaluse põhjalikuks etnoihtüoloogiliseks analüüsiks. Mida paremini on uuritud rahvakeelseid nimetusi ja kirjeldatud rahvapärast süstemaatikat, seda selgema tausta annab see tänapäeva keelekorraldajatele ja etümoloogidele. Et rahvapärased nimetused viitavad millelegi kalale iseloomulikule, on sellised nimed arusaadavamad, jäävad paremini meelde ning kannavad oma tähendussisu edasi. 


\section{Ülevaade kalanimetuste kujunemisest rahvapäraste nimetuste taustal}

Eestikeelseid kalanimetusi on üles märgitud sellest ajast peale, kui tekkis eesti kirjasõna. Kalanimetusi leidub meie varastes keelekäsiraamatutes (Stahl 1637, Gutslaff 1648, Göseken 1660, Hupel 1780/1818) ja Vestringi käsikirjas (u 1710-1730) nii palju, kui neid tol ajal tunti. Ühelegi nimetusele ei antud eesõigust, need olid üles märgitud sellisel kujul, nagu neid kohapeal tarvitati. Nii ilmneb Heinrich Stahli sõnastikus eeskätt Järva- ja Virumaa keel, Johann Gutslaffil Lõuna-Eesti keelepruuk, Heinrich Gösekenil läänemurre jne. Selline lähenemine on igati mõistetav, kuna sõnastikud olid mõeldud eelkõige sakslastele endile maarahva keelest arusaamiseks. Kindlamate terminite järele tekkis vajadus hiljem seoses koolihariduse laiema levikuga. Esimene teaduslikum käsitlus kaladest leidub Juhan Kunderi õpikus Looduse õpetus. I. raamat. Elajate riik (1877). Kalu käsitlevas peatükis on ta seal kalade kirjeldamise kõrval otsinud kalaliikidele ka sobivaid eestikeelseid nimesid. Laias laastus võib öelda, et J. Kunder on pannud nimed pooltele Eestis elutsevatele kaladele, mitmed neist on tänapäeval saanud uue rahvuskeelse nimetuse, nt eerus $>$ jõeforell, kivinool > vingerjas. Kõrgelt tuleb hinnata kõiki J. Kunderi loodusõpetuse-alaseid töid: tema panus loodusoskuskeele arengusse on tähelepanuväärne, ta on selle esimene teadlik ja süsteemne arendaja (Paatsi 2003: 95).

Esimene eesti kalaraamat Kodumaa kalad ilmus 1896. aastal Johann Gustav Spuhl-Rotalialt. See oli koostatud Saksamaal ja Venemaal ilmunud ihtüoloogiaalase kirjanduse eeskujul ning täiendatud kohalike andmetega. Kalade süstematiseerimisel on J. G. Spuhl-Rotalia lähtunud teaduslikust taksonoomiast, liigitades kalad süstemaatilisse hierarhiasse. Taksonite nimetused aga peegeldavad tal rahvapärast lähenemist - iga liigi kohta on autor esitanud kõik talle teadaolevad nimetused, lisaks on ta neid üritanud ka ise (peamiselt saksa keele eeskujul) luua. Nii näiteks esineb Spuhl-Rotalial kõrvuti haug ja purikas, koger ja karus, koha ja sudak, lõhe ja laks, võldas ja kivitrull, kammeljas ja kivilest (< sks Steinbutt), nolgus ja mereskorpion (< sks Seescorpion), rünt on aga esindatud koguni nelja nimetusega: rünt, maidel, kivikala ja ürilane. Mõnel juhul on see põhjendatav meie murdekeelega, sest piirkonniti tuntakse ühte kala eri nimetustega: näiteks läänepoolses Eestis valitseb $k o h a$, seevastu kogu Eesti idaosa on vallutanud venelaenuline sudak. Et J. G. Spuhl-Rotalia oli eelkõige rahvavalgustaja, kelle eesmärk oli tutvustada Eestis elutsevaid kalu, teenibki selline lähenemine kõige otsesemalt rahva huve, et võimalikult palju inimesi saaks aru, kellest jutt. 


\section{Üks nimi, mitu kala; üks kala, mitu nime}

J. Kunder seevastu on oma loodusloo õpikus püüdnud kalade loendis esitada ladina nimetustele ühe eestikeelse vaste ning hiljem kalade kirjelduste juures toonud ka sünonüümid. Nii on tal Gobio gobio vasteks rahvapärane omasõna kivikala võõrapärase ründi asemel. Kivikala on eesti murretes üldse väga produktiivne nimetus, mis võib märkida vähemalt nelja kalaliiki (nt rünt, võldas, hink, lepamaim). Kala eluviise arvestades oleks ehk kõige õigustatum, kui seda nime kannaks võldas - tema elupaigaks on mõne suurema kivi servaalune, kus ta enamuse aastast istubki, tehes vaid öösiti lühikesi toidurändeid. Venelastel ongi võldase teaduslikuks nimetuseks обыкновенный подкаленщик, soomlastel kivisimppu (murretes ka kivikala, kivinilkki) ja rootslastel stensimpa. Spuhl-Rotalial on võldase paralleelnimeks kivitrull, ning lisaks kivikalale ja -trullile on meie võldase rahvapäraseid nimetusi kivikana, kivinakker, kivipõnk. Eesti etümoloogiasõnaraamat (EES) ütleb, et võldase puhul on tegu tundmatu päritolu tüvega (EES 616), kala ametlikku nimetust pole registreeritud ka eesti murretest. Olgu siinkohal öeldud, et eestikeelsete rahvapäraste liitsõnaliste kalanimetuste juures on suures ülekaalus just kivi-algulised nimetused, neid on rahvasuus moodustatud üle 50 (vt ka Kendla 2005). Ükski neist pole aga saanud mõne kala kirjakeelseks nimetuseks.

Leidub ka juhtumeid, kus kivi- ei ole alati kõige põhjendatum valik. Näiteks on J. Kunderil Misgurnus fossilis'e vasteks kivinool. Vingerja rahvapärase nimetusena esitab selle ka Spuhl-Rotalia ning tema järgi meie järgmiste kalaraamatute autor Heinrich Riikoja (Kodumaa kalad 1927; Eesti NSV kalad 1950) veel oma 1950. aasta väljaandes (Spuhl-Rotalial ja Riikojal esinevad kivinoole kõrval veel kivinoolija ja kivijüraja). Meie kõige põhjalikuma kalaraamatu Eesti NSV kalade (1984) autor Neeme Mikelsaar aga leiab, et kivi-algulised nimetused ei sobi mudas elava vingerja nimeks, ja ta on kõik need varasemates kalaraamatutes esinevad nimetused oma loendist välja jätnud. Kivi-nimetusi, mis märgiksid vingerjat, ei leidu ka Eesti Keele Instituudi murdesõnavara kartoteegis. Mudalembese kalana on vingerjas soome keeles mutakala ja saksa keeles Schlammpeitzker, ka meie rahvapäraseid vingerja nimetusi on mudakala, mudamadu, mudasilm.

\section{Kivinool, vingerjas ja ilmakala}

Nimetuse kivinool juures on aga põhjust peatuda pikemalt. Vanemas kirjakeeles esineb see Heinrich Gösekenil, kelle huviorbiidis oli ka loodussõnavara, ent eestikeelne nimetus vääris ülesmärkimist eelkõige seetõttu, et tegu oli eesti 
sõnaga: kiwwi nohl 'meerSchnecke ostrea'; 'Steinwurm'. Oma loodussõnade puhul on $\mathrm{H}$. Göseken olnud korduvalt segaduses saksa, ladina ja eesti vastete seostamisel, ja ka kivinoole puhul jääb selgusetuks, mis looma ta on mõelnud. Gösekeni uusväljaandes on see tituleeritud kalaks: '(kala)' (Kingisepp jt 2010: 417), F. J. Wiedemanni sõnaraamatus on kivinoole vasteks trulling: kivinooĺ 'Peizker (Cobitis L.)'(Wied 680). Rahvasuus on kivinooleks, kivinooljaks, ka kivijärajaks, -jürajaks ja -närijaks kutsutud hinku (Cobitis taenia). Kõik kõnealused kalad: vingerjas, hink ja trulling (Nemacheilus barbatulus) kuuluvad hinklaste sugukonda, väliselt on omavahel sarnasemad hink ja trulling. Nii kohtame ka trullingul rahvapäraseid nimetusi kivijäraja ja -jüraja. Õigupoolest sobiksidki kivi-nimetused kõige paremini trullingule: ta on kiirevooluliste kivise põhjaga jõgede kala, kes suudab pugeda ka kivide alla. Sama meelt on soomlased ja inglased, kellel on trulling vastavalt kivennuoliainen ja stone loach, samas sakslaste Steinbeisser tähistab hinku. Huvitavad nimed on pannud kaladele lätlased. Nemad klassifitseerivad hingu kivinärijaks (akmengrauzis) ja trullingu habemega kivinärijaks (bārdainais akmengrauzis). Kui rääkida "habemest", siis zooloogilise terminoloogia järgi on mõlemal kalal ühepalju (3 paari) poiseid, aga trullingul on need pikemad. Ka meie rahvapärseid trullingu nimetusi on pardavaar, parrakas, pardalõug.

Kust tuleb aga nimetus vingerjas? Vingerjas on $15-18 \mathrm{~cm}$ pikkune pikliku kehaga kala. Usja liikumisviisi tõttu võiks tema nime seostada vingerdamaverbiga, ent kui vaadata vingerja rahvapäraseid nimetusi, võib pigem väita, et tegu on ühe häälitseja-kalaga, kes vingub, kidiseb, kiitsub ja k(r)äunub: vigiseja, vigine, vingjas ('vińgjase vinguve $k u$ 'vällä võets Hls), vingur ('vingurid `vinguvad `jusku `iired kidiseväd Lüg), vigijas (vigijat röögivad käreda eliga TMr), kidijas, kidiseja, kiids (kiidsu? umma? pikä? peenikese? kala, kui jalg pääle putuss, siss tege kiids-kiids-kiids Rõu), kiidsukala (kiidsukala, tuu mis hellü tege Rõu), käunam ('käunämäd, mustad peeniksed kalad, jusku uśs, karjub käun-käun Kõp), käunjas, kräunam. Niisiis vingerjas pigem vingub kui vingerdab. Seoses mudaeluviisiga on vingerjal toimetulekuks välja kujunenud soolehingamine, ning selline "häälitsemine" on tingitud gaaside väljumisest sooltorust (Mikelsaar 1984: 251).

Siinkohal ei saa mainimata jätta veel ühte vingerja omapära: vingerjas tajub nii aeglasi kui ka järske rõhumuutusi, mida võimaldab spetsiaalne ujupõie ehitus ja seetõttu on teda peetud akvaariumikalana "ilmastikuprohvetina" (Mikelsaar 1984: 251). Nimelt tuleb kala õhurõhu langedes ehk vee hapnikusisalduse langedes veepinnale õhku neelama. Nii et kui vingerjas ujub pinnale, on see märgiks, et vihmavari tuleks välja minnes ühes võtta. Inglaste keelevaist ongi klassifitseerinud vingerja ilmakalaks - weatherfish. 
Põhjamaades on aga ilmakaladeks (rootsi k väderfiskar) liigitatud mõnevõrra sarnased, nõelja kehakujuga kalad, kes riputati kuivatatult lakke tuulesuuna teadasaamiseks. Sellised kalad on merinõel (Syngnathus typhle), madunõel (Nerophis ophidion), suurtobias (Hyperoplus lanceolatus), väike tobias (Ammodytes tobianus), tuulehaug (Belone belone) ja raudkiisk (Spinachia spinachia), kes on veel huvitav selle poolest, et teda on klassifitseeritud ka kui külmatõvekala - nimelt soovitatud külmetamise korral raudkiisa tuhka sisse võtta (Mägeri kartoteek). Eestlased on need kalad kategoriseerinud tuulekaladeks. Kuusalus on merinõela kohta öeldud, et sie 'pandi lage rippuma, et sie näüt siis, kust puolt tuult tuleb, et siis `kieräb nenä `sinne 'vastu tuuld. Seotust tuulega näitavad veel mitmed nende kalade rahvapärased nimetused: tuuleling, tuulenool, tuulenõel, tuulenäitaja, tuuleuss, tuuleving, tuuleviuk (Nie ‘tuule viugud `nä̈̈äväd kohe, ku kuo tuod, kust puold tuul on, neh `kierdäväd nenä 'tuule ‘puole rippujess Kuu) jt. Soomlastel on aga tobiad suur ja väike tuulekala: isotuulenkala ja pikkutuulenkala. Komme kasutada ilmakalu kui rahvalikke baromeetreid püsis Põhjamaades kuni eelmise sajandi alguseni (Svanberg 2000: 26).

\section{Rahvapärase nimeandmise teistest alustest}

Eespool oli mitmeid näiteid, kuidas rahvas on kalu kategoriseerinud (ilmakalad, tuulekalad) ja mille järgi kalu nimetanud. Siinkohal saab peatuda veel mõnel põhimõttel. Näiteks välimuse järgi on tuulehaugi nimetatud nokahaugiks, nokakalaks, pikanokakalaks - liigi eripäraks on pikaks nokaks venitunud lõuad, millest alumine on pisut pikem. Sellest tulenevad ka soome nokka-, sarvihauki, nokkakala, saksa Hornhecht, Hornfisch, rootsi näbb-, horngädda, hornfisk.

Kala välimus ongi põhilisemaid kalade eraldamise tunnuseid, mis on olnud üks peamisi nimeandmise aluseid. Enim on siin vanarahvast inspireerinud ogaliku (Gasterosteus aculeatus) või luukaritsa (Pungitius pungitius) kehal paiknevad ogad: nagapoiss, ogajurka, ogapoiss, odapoiss, okkakala, okkarull, piigiline, piikmaim, piikselg jne, ülekantud tähenduses ka kassiperselõhkuja, perserookija. Kui meie ogaliku järgi võib enam-vähem kala väljanägemist ette kujutada (eks ta üks ogadega kala peab olema), siis luukaritsa puhul on see juba keeruline. Ogaliku kehal on kolm tugevat seljaoga, luukaritsal paikneb seljauime ees 7-12 (tavaliselt 9-10) sissetõmmatavat oga, nii on kalade ametlikud nimetused teistes keeltes vastavalt soome kolmipiikki, vene трехиглая колюшка, saksa Dreistachliger Stichling, inglise three-spined stickleback ning soome kymmenpiikki, venе девятииглая колюшка, inglise nine-spined stickleback ja läti devingadatu stagars. 
Kiisa nimetused okaskala, harjakala, harjamees viitavad kala teravale seljauimele, aga on oma luisuse tõttu tuntud ka kui ämmatapja. Angerjas on siug, uss, veeuss, usskala ning väikest angerjat on kutsutud saapapaelaks, ja seda mitte ainult välimuse tõttu, vaid Reigis teatakse, et väikese angerja nahka kasutatigi saapapaelaks: angerjal võeti nahk maha, pandi liiv sisse, kuivatati niimoodi ära ja pärast tehti rasvaga pehmeks.

Väga iseloomulikeks merivarblase (Cyclopterus lumpus) rahvapärasteks nimetusteks on seitsmekandiline ja seitselg: kui kala on muidu soomusteta, siis kummalgi pool keha on tal kolm horisontaalrida luutüükaid, lisaks üks rida selja keskjoonel, mis jätab mulje justkui seitsmest seljast. Haljalas on öeldud: seitselg, 'veike must merekala, 'rasvane, ‘kiedetä `saapa'määret - selle omaduse järgi on aga Viru-Nigulas merivarblane liigitatud rasvakalaks. Sellised tähelepanekud loodusest enesest on andnud rootslastele merivarblase rahvuskeelseks vasteks sjurygg ja soomlastele rasvakala. Meie merivarblane pärineb aga vene keelest (vrd vn морской воробей 'merivarblane'), Wiedemanni sõnaraamatus on kala vasteks saksa keele eeskujul merejänes 'Seehase, Lump (Cyclopterus Lumpus L.)' (Wied 147). Eesti Keele Instituudi murdekartoteegis ei ole teateid merejänese esinemisest eesti murretes, merivarblase nimetust tuntakse siiski Tõstamaal ja Saaremaal, kus on rohkem kasutusel nimetus munder, kuna kala vahetab kudemise ajal värvi. Merivarblast on nimetatud veel kassikalaks, kuna kõlbas anda üksnes kassile, ja mündikalaks, mis tuleneb sellest, et hädakaubakalana teiste kalade puudumisel maksti tema eest üks sent tükk.

Tõlkelaenulist päritolu on ka meie vinträime (Alosa fallax fallax) nimetus, mis lähtub vene фбинта'st või saksa Finte'st. Värvuselt on vinträim tumeda selja ja hõbedaste külgedega kala, tema eritunnuseks on aga kuus kuni üheksa tumedat täppi külgedel, neist ka rahvapärased nimetused nagu täpikala, tipuline. Täppide järgi on vinträime nimetanud ka soomlased (täpläsilli).

1959. aastal kirjutas Vassili Kossatkin, et meie tippviidika (Alburnoides bipunctatus) nimetus on kunstlikult loodud ladinakeelsest sõnast punctatus. Kalal ei esine mingeid iseloomulikke tippe, kui nendeks tippudeks mitte pidada väikesi musti täpikesi kala küljejoonel, aga need täpid ei õigustavat tippviidika nimetust. Puht-eestiliseks, tõeliselt rahvapäraseks nimetuseks peab ta kiviviidikat, ning nendib samas, et kõige õigem oleks tippviidikat nimetada põhjaviidikaks, sest kala elutseb tavaliselt jõe põhjavees. (Kossatkin 1959: 250-251.) Rahvapäraseid nimetusi sel vähelevinud kalal kuigi palju ei ole, lisaks kiviviidikale veel kose- ja sohiviidikas, sest erinevalt tavalisest viidikast (Alburnus alburnus) eelistab tippviidikas kiirema vooluga kivise põhjaga jõgesid ning merevette ei satu ta üldse. 
Salmo trutta trutta morpha fario kirjale (kala küljed, selg ja seljauim on kaetud punaste, pruunide ja mustade erinevas suuruses tähnidega) viitavad sellised rahvapärased nimetused nagu kires, kirevkala ja tähnik, mis on kala vasteks ka Spuhl-Rotalial. Praeguses ihtüoloogilises terminoloogias on kala nimetuseks jõeforell (< sks Bachforelle); seda nime aga rahvasuus ei tunta. Lisaks jõeforelli kirjale viitavatele nimetustele tuntakse Lõuna-Eestis kala hõrnasena. Nimetuse leiame ka varasemast kirjandusest: hörn 'eine Forelle' (Hupel 1818: 45); hõrn, hõrnas 'Forelle (Salmo Fario L.)' (Wied 741). Kui hõrnas on meie rahvuskeelseks vasteks veel H. Riikoja Kodumaa kalades, siis jõeforell on saanud kala ametlikuks nimetuseks sama autori 1950. aasta väljaandes. Enam-vähem samasuguse muutuse on läbi teinud ka meriforell (Salmo trutta trutta), mis pärineb samuti saksa keelest (< sks Meerforelle) - nimetus on fikseeritud meie rahvuskeelseks vasteks H. Riikoja Eesti NSV kalades. Eesti murretes tuntakse kala iherusena, sõna esineb ka vanemas kirjakeeles ja Wiedemannil: Eheris 'Forelle' (Gutslaff 1648), Ehheris 'Forel (Erlitz)' (Göseken 1660: 505), ihheris d. 'Lachsforelle' (Hupel 1818: 52); iherüs (g) iherüse (d) (eheros, eherus) 'Lachsforelle (Salmo Trutta L.)' (Wied 112). Ent kalade varasemad nimetused hõrnas ja iherus elavad keeles edasi tänapäevalgi. Kui ma 2012. aastal küsitlesin inimesi rahvapäraste kalanimetuste kohta, oli üks noor Lõuna-Eestist pärit informant veendunud, et hõrnas ongi kala ametlik nimi, mitte murdenimi. Mõlemad rahvapärased nimetused esinevad ka õigekeelsussõnaraamatus (ÕS 2013: 217, 229).

Eelpool oli näiteid, kuidas kalad on saanud nimesid kirja järgi (nt täpikala, kirevkala). Kui peatuda veel kala välimusel, on üks oluline näitaja kala värvus. Mitmele kalaliigile on iseloomulik hõbedane läige, millest tulenevad nimetused hõbekoger, hõbelatik, hõbelõhe (vrd soome hopealohi), hõbekala hõbenool 'räim', hõbesalakas 'viidikas'. Heledama värvusega kalu iseloomustatakse täiendsõnaga valge: valgekala 'merisiig', 'räim', 'viidikas', valgesärg, valgeviidikas. Kullaläikeliste külgedega roosärg on kuldsärg. Roosärge peetakse Eestis üldse üheks ilusamaks kalaks tema erksate värvide tõttu: lisaks kullatoonistele külgedele ehivad teda üleni veripunased päraku- ja kõhuuim, ent punast esineb kõigil uimedel. Sellest tulenevalt on roosärg punane särg, punaseuimesärg, punapüks (vrd soome punajalka, punapyrstö, punauimunen, vene краснопёрка, saksa Rotfeder, Rothauge, rootsi rödfena, rödmört, taani rødskalle, inglise red-eye).

Väga määrav kategooria kalade puhul on nende elupaik. Valdavalt on sellised nimed liitsõnalised, kus täiendsõna viitab veekogule ning põhisõna kalale, nt jõekirjak, jõehavi, merehunt 'haug' (vrd soome jokihauki); jõekiisk, merekiisk; järveahven, mereahven; järvekoger, tiigikoger (vrd soome järvikouri); 
järvekurat 'võldas'; merehulgus 'tursk', 'räim', 'heeringas' jne. Näidetest selgub muu hulgas, et rahvas eristab samu kalaliike selle järgi, millisest veekogust kala on püütud. Teaduslikust taksonoomiast võiks näitena tuua meritindi (Osmerus eperlanus eperlanus) ja peipsi tindi (Osmerus eperlanus eperlanus morpha spirinchus) ning merisiia (Coregonus lavaretus lavaretus) ja peipsi siia (Coregonus lavaretus maraenoides). Peipsi tinti peetakse meritindi mageveeliseks vormiks (morpha), peipsi siig on Peipsi järves väljakujunenud siiavorm. Rahvasuus ei eristata neid kalaliike elupaiga järgi, vaid räägitakse tindist ja siiast. Millisest liigist jutt käib, saab aimu üksnes selle järgi, kust nimetus on registreeritud: rannaalade inimesed tunnevad mereliike ja Peipsi ümbruse elanikud järvevorme. Tindikala on oma spetsiifilise lõhna tõttu rahvasuus kategoriseeritud haisukotiks, hobuselihapoisiks, tallipoisiks (saksakeelne tindi nimetus Stint võib lähtuda sõnast stinken 'haisema, lehkama', samuti inglise smelt 'meritint' < smell 'id.'). Siiakala on aga saunakala, sest siig viidi sauna nurganaisele kui väärtuslik kala.

Inimestele on kalade juures oluline nende kudemis- ehk siis ka optimaalne püügiaeg (varem püüti kalu nende kudemisajal). Need tähelepanekud on seotud otseselt looduses toimuvate muutustega, ja et kalu sel viisil liigitada, peavad inimesed täpselt teadma kalade ökoloogiat. Enim on kudemisjärke eristatud latikal (Abramis brama). Särjelatik koeb mai esimesel poolel koos särjega (samamoodi on seda kudemisjärku nimetanud soomlased, nende murretes esineb särkiäislahna 'kevad-suvel kudev latikas'). Sel ajal kudevat latikat on nimetatud ka jürilatikaks. Toomelatik koeb mai lõpus või juuni alguses. Võrtsjärve kalurid nimetavad toomelatikat veel pärislatikaks kui kõige arvukamat. Toomelatikaga samasse aega jääb nigulalatik 'suvistepühade paiku kudev latikas'. Õnapuude õitsemise aegne latikas on urvandilatik, uibulatik ja õunapuuõie latik ning rukki õitsemise aegu püütav latikas rukkiõielatik(as). Hilisemad kudejad on jaanilatik ja kesalatik. Toomingate õitsemine on märgiks mitme kalaliigi kudemisaja saabumisest: toomeviidik, toomevimb, toomingahaug, toomingaõieräim. Toomingas on üldse rahvapärimustes väga tähtsal kohal. Tema õitsemisel ja viljumisel on oluline koht põllutööde orientiirina, aga ka saagi- ja ilmaennetes (Hiiemäe \& Tuisk 2010: 58).

Ülaltoodud on tüüpnäited rahvapärasest kategoriseerimisest, aga võib öelda, et ampluaa on laiem. Kui rahvuskeelseks teaduslikuks taksoninimetuseks saab igal liigil olla üks fikseeritud nimi, siis rahvasuu lähtub kalade nimetamisel paljudest omadustest. Mainitagu veel kala suurust, kus tavaliselt on silmas peetud mõne liigi väikeseid isendeid, nt (ahvena) kirp, moks; (havi) nolk, nilks; (siia) mann, muik; (säina) mürk, põnnak, aga ka suuri: hiigla hobulest 'hiidlest', käsivars 'suur angerjas', labakas 'suur latikas'. Kalade väiksust võidakse väljen- 
dada ka teise kalaga, kusjuures kõnealune kala võib olla nii täiend- kui põhisõna positsioonis, nt särjeahunas 'väike ahven'; särjeviidikas, kilusärg 'väike särg'; siiakilu 'väike siig'. Püügikohale viitavad Tibrika hulgus 'Tibrikalt püütud räim', Salatsi tursk 'Salatsi madalikult püütud tursk', püügiviisile mutikiisk, mõrraahven, nooda-, rüsa-, võrguräim, õngeangerjas. Nimetustes peegeldub seegi, mis söödaga nad püütud on, nt lutsu-, ogarulli-, räimeangerjas. Kalade puhul on oluliseks momendiks nende väärtus toidulaual, ent tähtsust omasid ka söödakalad, vrd unnasärg 'unnasöödaks kasutatud särg', siiasööt 'väike mudilake', raudpea 'noor säinas' (visa hingega kala, mistõttu sobib hästi õngesöödaks). Omamoodi kõnekas on seegi fakt, et põhilistele püügikaladele antud nimetuste hulk on võrreldav tähtsuseta võrkusattujatega, kes oma silmatorkava välimusega on nimeandjaid vaat et rohkemgi inspireerinud.

\section{Lõpetuseks}

Eestikeelsete loodusnimede loojaid on olnud palju, tegutsenud on taime- ja linnunimede komisjonid. H. Riikoja mainib oma kalaraamatute eessõnas, et ka neis esitatud eestikeelsed kalanimetused on fikseerinud vastav komisjon. N. Mikelsaar on eestikeelsete teaduslike nimede puhul toetunud 1972-1973 ihtüoloogide ja keeleteadlaste ühisnõupidamistel kokkulepitud nimetustele. Niisiis on eesti kalade praegu kehtivad rahvuskeelsed vasted fikseeritud 1984. aastal N. Mikelsaare teoses Eesti NSV kalad. Peab märkima, et meie kirjakeelsed nimetused ei toetu kuigivõrd rahvapärastele, isegi kui raamatu eessõna märgib, et "eestikeelsete nimede valikul tuleb eelistada rahvakeeles levinumat nime, s.o tugineda suupärasuse ja kergema äratundmise põhimõttele, jättes taksonoomiliste kategooriate fikseerimise ladinakeelsete nimetuste ülesandeks". Määravaks on saanud ilmselt asjaolu, et kalanimetuste käsitlused on (alates H. Gösekenist) lähtunud eeskätt bioloogilisest süstemaatikast ja teiste maade eeskujust rahvuskeelsete nimetuste moodustamisel. Kirjakeelne terminoloogia taotleb üldtuntust ja üheselt fikseeritud sõnakuju, eesti rahvapärased kalanimetused on aga sageli piirkondlikud, kitsama levikuga ja nende üldtuntusest rääkida ei saa. Torkab silma, et isegi kui oleks olnud võimalust valida terminiks deskriptiivseid nimetusi kaladele iseloomulike tunnuste järgi, pole seda eelistatud - nt trulling (alamsaksa laen) pro kivijäraja, merivarblane (tõlkelaen vene keelest) pro seitselg, rasvakala. Paistab, et soomlased on omasõna sagedamini eelistanud (vrd kivennuoliainen 'trulling' või rasvakala 'merivarblane'). 
Linnu- ja taimenimetuste uurijad aga tõdevad, et taimede teaduslike nimetuste määramisel on olnud aluseks enam levinud rahvapärane nimetus (Kalle \& Sõukand 2011: 77), linnunimetuste puhul on lähtutud samuti rahvalikest nimetustest ja peetud silmas üldisi aluseid: vormi, värvi, eluviisi, elupaika (Mäger 1967: 197).

Siiski saab ka kalanimetuste puhul rääkida juhtumist, kus teadusliku nimetuse aluseks on saanud rahvapärane. N. Mikelsaar väidab, et Spuhl-Rotalia poolt ladina keele eeskujul kunstlikult loodud liiperkala (Liparis liparis) peaks loovutama koha rahvakeelest võetud nimetusele pullukala, kuna kala imeb ennast püüniste pullude külge (vrd soome rahvuskeelset vastet imukala). Nii on varasem kala nimi liiperkala asendunud teaduslikus terminoloogias rahvapärase pullukalaga, selles nimes peegeldub kalale iseloomulik käitumismaneer.

Kõige loomulikumad nimetused ongi need, mille on loonud rahvas oma arusaamade järgi ja oma keele eripära kohaselt. Rahvapärane deskriptiivne süstemaatika lähtub printsiipidest, mis kalu kõige paremini iseloomustab. Võib öelda, et eesti rahvalike kalanimetuste süsteem on kujunenud põhiliselt oma leksika baasil, teaduslike nimede panekul on aga arvestatud rahvusvahelist konteksti ja tihti on lähtutud teiste keelte eeskujust (eriti saksa keele näol).

\section{Kommentaar}

1 Aeg-ajalt satub meile eksikülalisi või on mõni liik töönduslikel eesmärkidel sisse toodud. Sellistel (nt ameerika paalia, peled, pollak) on koht eesti kalade süsteemis, aga vanarahvas neid ei tundnud ja seega pole neil ka rahvapäraseid nimetusi.

\section{Allikad}

EKI MK = Eesti Keele Instituudi murdesõnavara kartoteek

EKI MKK = Eesti Keele Instituudi Mart Mägeri kalanimetuste kartoteek

\section{Kirjandus}

Castetter, Edward F. 1944. The Domain of Ethnobiology. The American Naturalist 78, lk 158-170.

Cruse, D. Alan 1986. Lexical Semantics. Cambridge: Cambridge University Press.

EES = Metsmägi, Iris \& Sedrik, Meeli \& Soosaar, Sven-Erik (koost) 2012. Eesti etümoloogiasõnaraamat. Tallinn: Eesti Keele Sihtasutus. 
Gutslaff, Johann 1648. Observationes grammaticae circa linguam Esthonicam... Dorpati Livonorum: Johannes Vogel.

Göseken, Heinrich 1660. Manuductio ad Linguam Oesthonicam. Anführung Zur Öhstnischen Sprache. Reval: Gedruckt und verlegt von Adolph Simon.

HERBA = Sõukand, Renata \& Kalle, Raivo (koost) 2008. Historistlik eesti rahvameditsiini botaaniline andmebaas (http://herba.folklore.ee - 10. aprill 2014).

Hiiemäe, Mall \& Tuisk, Astrid 2010. Toomingas rahvapärimustes. Eesti Loodus 5, lk 58-59 (http://www.eestiloodus.ee/artikkel3323_3277.html - 10. aprill 2014).

Hupel, August Wilhelm 1818. Ehstnische Sprachlehre für die beyden Hauptdialekte, den revalschen und dörptschen, nebst einem vollständigen ehstnischen Wörterbuche. Zweyte durchgängig verbesserte und vermehrte Auflage. Mitau: J. F. Steffenhagen und Sohn.

Kalle, Raivo \& Sõukand, Renata 2011. Omanimetus või õige nimetus? Eestlaste ravimtaimetundmise alustest. Akadeemia $1,1 \mathrm{k} 62-81$.

Kendla, Mari 1997. Saare- ja Muhumaa kalanimetused. Preprint. Tallinn: Eesti TA Eesti Keele Instituut.

Kendla, Mari 1999. Lä̈̈ne-Eesti kalanimetused. Tallinn: Eesti Teaduste Akadeemia Eesti Keele Instituut.

Kendla, Mari 2005. Liitsõnalised kalanimetused eesti murretes. Keel ja Kirjandus 12, lk 978-983.

Kingisepp jt 2010 = Kingisepp, Valve-Liivi \& Ress, Kristel \& Tafenau, Kai. Heinrich Gösekeni grammatika ja sõnastik 350. Tartu: Tartu Ülikool.

Kossatkin, Vassili 1959. Tippviidikas - Eesti haruldane kala. Kumari, Eerik (toim). Loodusuurijate Seltsi aastaraamat 51 (1958). Tallinn: Valgus, lk 249-262.

Kull, Kalevi \& Koppel, Andres 1989. Elusolendite rahvuskeelsest nimetamisest. Eesti Loodusuurijate Seltsi aastaraamat 71. Tallinn: Valgus, lk 184-193.

Kunder, Juhan 1877. Looduse õpetus. I. raamat. Elajate riik. Koolmeistritele ja koolidele kirja pannud Johann Kunder. Tartu: Schnakenburg.

Mikelsaar, Neeme 1984. Eesti NSV kalad. Käsiraamat-määraja. Tallinn: Valgus.

Morrill, Warren T. 1967. Ethnoichtyology of the Cha-Cha. Ethnology 6, lk 405-416.

Mäger, Mart 1961. Eesti linnunimetuste alused. Emakeele Seltsi aastaraamat VII. Tallinn: Eesti NSV Teaduste Akadeemia Emakeele Selts, lk 54-73.

Mäger, Mart 1967. Eesti linnunimetused. Tallinn: Eesti NSV Teaduste Akadeemia Keele ja Kirjanduse Instituut.

Mäger, Mart 1973. Juhend ja nimestik kalanimetuste kogumiseks. Tallinn: Eesti NSV Teaduste Akadeemia Emakeele Selts.

Paatsi, Vello 2003. Eesti talurahva loodusteadusliku maailmapildi kujunemine rahvakooli kaudu (1803-1918). Tallinna Pedagoogikaülikooli Sotsiaalteaduste dissertatsioonid 5. Tallinn: TPÜ Kirjastus. 
Riikoja, Heinrich 1927. Kodumaa kalad. Abiraamat kalade tundmaõppimiseks. Tartu: Loodus.

Riikoja, Heinrich 1950. Eesti NSV kalad. Abiraamat kalade määramiseks ja tundmaõppimiseks. Tallinn \& Tartu: Eesti Riiklik Kirjastus.

Spuhl-Rotalia, Johann Gustav 1896. Kodumaa kalad, Eesti-, Liivi-ja Kuramaa vetes ning Läänemeres elutsevate kalade looduselugu, nende pü̈̈dmine kunstiliste abinõudega, kasvatamine, kunstlik sugutamine ja kalaliikide asutamine. Viljandi: A. Peet.

Stahl, Heinrich 1637. Anführung zu der Esthnischen Sprach, auff Wolgemeinten Rath, und Bittliches Ersuchen, publiciert von M. HENRICO Stahlen. Revall, Druckts Chr. Reusner der älter, in Verlegung des Authoris. M.DC.XXXVII. Revall: H. Stahl.

Svanberg, Ingvar 2000. Havsråttor, kuttluckor och rabboxar. Folking kunskap om fiskar i Norden. Stockholm: Arena.

Sõukand, Renata \& Kalle, Raivo (koost) 2008. Historistlik eesti rahvameditsiini botaaline andmebaas (HERBA) (http://herba.folklore.ee - 17. aprill 2014).

Vestring, Salomo Heinrich 1998. Lexicon Esthonico Germanicum. Kaldjärv, Ellen (toim). Tartu: Eesti Kirjandusmuuseum.

Vilbaste, Gustav 1993 = Ahven, Eeva \& Ahven, Heino \& Parmasto, Erast (toim). Eesti taimenimetused $=$ Nomina vernacula plantarum Estoniae. Eesti TA Emakeele Seltsi Toimetised nr 20 (67). Tallinn: ETA Emakeele Selts.

Wied = Wiedemann, Ferdinand Johann 1973. Eesti-saksa sõnaraamat. Estnisch-deutsches Wörterbuch. Neljas, muutmata trükk teisest, Jakob Hurda redigeeritud väljaandest [1893]. Tallinn: Valgus.

ÕS 2013 = Maire Raadik (toim). Erelt, Tiiu \& Leemets, Tiina \& Mäearu, Sirje \& Raadik, Maire (koost). Eesti õigekeelsussõnaraamat ÕS 2013. Eesti Keele Instituut. Tallinn: Eesti Keele Sihtasutus. 


\title{
Summary
}

\section{Fish Names in Estonian: Scientific Versus Common}

\author{
Mari Kendla
}

Keywords: Estonian dialects, ethnoichthyology, fish names, lexicology

The article gives an overview of the evolution of Estonian fish names, bringing to the fore the principles of naming fish from the point of view of both popular and scientific categorisation, and juxtaposing with the principles of classification of fish names by other peoples. The standard formal Estonian fish names started to be coined in the 1920s, when native-language terminology was created. Name-selection was often based on the example of other languages, especially German terminology. Estonian popular (dialect) names are based on local and popular categorisations, whereas the main emphasis is on the characteristic features of the fish. 